\title{
波亡流れの複合作用を受ける回転形浮体に働く流体力 WAVE AND CURRENT INDUCED FORCES ON VERTICAL AXISYMMETRIC FLOATING BODIES
}

\author{
松井 徹哉*, 李。相 曄** \\ Tetsuya MATSUI and Sang Yeob LEE
}

\begin{abstract}
A boundary integral equation method is developed for computing wave forces on large-volume axisymmetric floating bodies in weak current. The method is based on applying Green's theorem and expanding the velocity potential in a perturbation series of current speed. Retaining the leading-order terms in the current speed, the potential is obtained as the solutions of two sets of integral equations which only contain the Green's function at zero current speed. The solutions can be obtained efficiently by extending the standard boundary integral programs without current. Numerical results are presented for a number of body geometries. It is found that the wave exciting forces and the mean drift forces are most influenced by a small current speed.
\end{abstract}

\section{Keywords: wave, current, floating body, forward speed, hydrodynamic force, wave drift force, wave drift damping, boundary integral equation method}

波、流れ，浮体，前進速度、流体力，波漂流力，波漂流減衰、境界積分方程式法

\section{1. 序}

海洋構造物が波と潮流の作用を同時に受ける場合や波 浪中を史航される場合に作用する流体力を予測するに は，波と流れの共存場における流体力についての知識が 不可欠である。波之流れが共存する場合，波による流体 力は流れの存在によって著しい影響を受ける。この影響 は波漂流力に対して特に顕著であり、大型浮体の場合、 1-2 $\mathrm{ms}^{-1}$ の流速が加わることによって，波漂流力は流れ が不在の場合の 150-200\%に增加することもありうる。波 漂流力がわずかな流れによって著しく増加する事実は， 波浪中で長周期運動を行う係留浮体の重要な減衰機構 の存在を意味する。この減衰力増加は波漂流減衰 (wave drift damping) として知られ, 長周期運動を近似的に準 定常運動と見なすことによって，一様流れと波の共存場 における波漂流力の流速に関する微係数として評価され $ろ^{1), 2\}}$ 。

波と流れの共存場における流体力の問題は，波浪中を 一定速度で前進する船体の抵抗増加の予測と関連して，
船舶工学の分野では古くから研究の対象とされ，かなり の成果の蓄積がある。しかし，その多くは 2 次元的な細 長体理論 ${ }^{3), 4)}$ に基つくものであり, 海洋構造物のように 肥大な物体に対してはその成果を適用することはできな い。他方，任意形状物体にも適用できる 3 次元特異点分 布法5)は, グリーン関数の計算に特別の技巧と多大の労 力を必要とし, 実用解法とはなり難い。特に, 水面を貫 通する肥大物体で，物体の存在による流れの乱れ（定常 擋乱ポテンシャル）の影響が無視できないような場合に は，既存の一様流れ場におけるグリーン関数昼を用いる ことができないので，問題は一層複雑になる。このよう な困難を回避する方法として, Zhao et al. ${ }^{7}$ は流体領域 を流れの乱れが著しい物体近傍領域とそうでない遠方領 域に分割し，前者にはランキンソース（基本解）を，後 者には一様流れ場のグリーン関数を分布させ，2つの領 域の境界面で両者の解を接続ざせるハイブリッド型の解 法を提案している。

ところで，実際の海域における流れの速度や海洋構造
* 名古屋大学工学部建築学科 教授 $\cdot$ 工博

** 韓国安東工業専門大学建築設備科 講師・博士 (工学)
Prof., Dept. of Architecture, Faculty of Eng., Nagoya Univ., Dr. Eng.

Lecturer, Dept. of Architectural Equipment, Andong Technical Junior College, Korea, Dr. Eng. 
物が曳航される速度, あるいは係留浮体の長周期運動の 速度などは水粒子速度に比べて十分小さいと仮定でき る場合が多い。このような場合には，低流速の仮定を導 入することによって，より効率的な計算手続きの定式化 が可能である。たとえば, Huijsmans and Hermans ${ }^{8}{ }^{\text {は }}$ ソース分布とグリーン関数を流速に比例する揕動パラ メータのべき級数に展開し，流速の 2 乗項を省略するこ とによって、流れが遅い場合に有効な摄動論的近似解法 を提案している。ただし，一様流れ場のグリーン関数を 用いているので, 定常擋乱ポテンシャルの寄与は考慮さ れていない。

著者らは前稿9),10)において, 速度ポテンシャルに同様 の掑動展開を施すことによって, 流れが不在の場合の グリーン関数を用いて, 波と流れが共存する場合の流 体力を, 定常擋乱ポテンシャルの寄与をも含めて効率的 に計算する方法を提案した。類似の解法が最近 Nossen et al. ${ }^{11)}$ およひひ Grue and Biberg' ${ }^{12)}$ によって報告されて いる。かれらは, Huijsmans and Hermans ${ }^{8)}$ 之同様, 一 様流れ場のグリーン関数を用いているが，このグリーン 関数の流速依存項は積分路上に 2 位の極をもつため，そ の評価にはかなりの数値的困難が伴う。Huismans and Hermans ${ }^{8}$ はこの項が流れがない場合のグリーン関数の 微分によって表示できることを示しているが，その評価 には特別のアルゴリズムが必要であり, 物体表面上での 特異積分の処理などの問題も新たに生ずる。著者らの方 法によれば，流れが不在の場合のグリーン関数を用いる ので，一様流机場のグリーン関数に基づく既往の解法に 比べて,グリーン関数の計算に要する労力が少なくてす み, 既存の回折プログラムを拡張するだけで，容易に流 れの影響を考慮することができる。

前稿9),10)では，この解法を一様鉛直円柱および半球形 浮体に適用し，波による流体力が流れの存在, 特に物体 の存在による流れの乱れによって著しい影響を受けるこ とを明らかにした。本稿では，これを任意の子午線形状 を有する回転形浮体に適用できるように拡張する。前稿 10) 之異なるところは，定常擋乱ポテンシャルが関係する 部分のみであるから，その取扱いについてはやや詳しく 議論するが，それ以外の定式化については必要最小限の 記述にとどめる。応用例として, 鉛直円柱, 円筒形浮体 およびフラスコ形浮体の計算結果を示し，流体力や浮体 の運動応答に及ぼす流れの影響について考察する。

\section{2. 境界值問題}

一様な流れと規則波の複合作用を受ける回転形浮体を 考える。浮体は漂流移動が拘束されている以外は自由な 運動が許容されているものとする。空間固定座標系 $o$ $x y z$ を， $z=0$ が静水面に， $x$ 軸が流れの方向に， $z$ 軸が 浮体の回転軸に一致するように設定する (Fig. 1)。

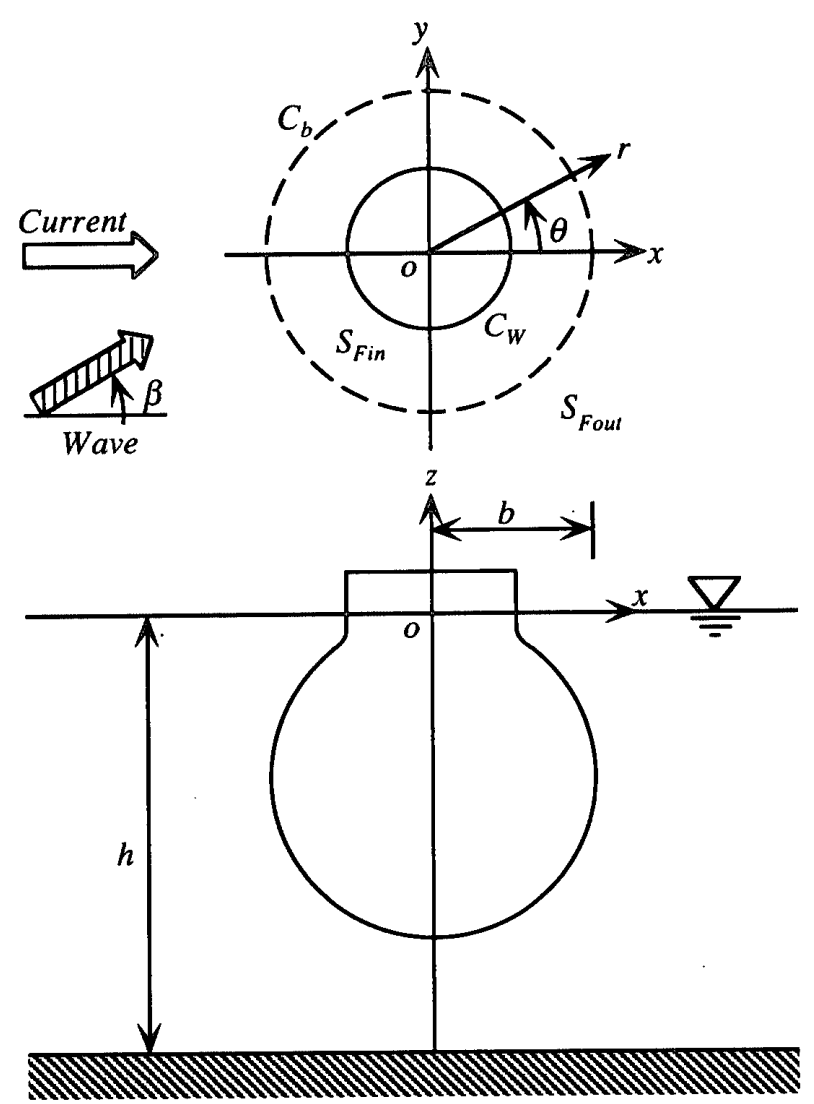

Fig. 1 Sketch of floating body in current and waves.

浮体の運動および入射波の振幅は微小で, 線形重ね合 わせが成り立つものと仮定する。浮体の運動は 6 自由度 の剛体モード（サージ $\Xi_{1}$, スウェイ $\Xi_{2}$, ヒーブ $\Xi_{3}$, ロー ル $\Xi_{4}$, ピッチ $\left.\Xi_{5}, \exists ー \Xi_{6}\right)$ の重外合わせによって表現 される。

流速を $U$ ，入射波の振幅を $\zeta_{0}$, 周波数を $\omega_{0}$, 波数を $k$, 入射波の伝播方向が $x$ 軸となす角度を $\beta$ とする。波数 $k$ と周波数 $\omega_{0}$ は次の分散方程式によって関係つけりれる。

$$
k \tanh k h=\frac{\omega_{0}^{2}}{g} \equiv \nu_{0}
$$

ここに， $g$ は重力加速度を， $h$ は水深を示す。

浮体の運動振幅は, 時間 $t$ において, 次式のように記 述される。

$$
\Xi_{j}=\operatorname{Re}\left[\xi_{j} e^{-i \omega t}\right], \quad j=1, \ldots, 6
$$

ここに，山は出会い周波数を示し, 次式によって定義さ れる。

$$
\omega=\omega_{0}+k U \cos \beta
$$

流体は非粘性，非圧縮性の理想流体で，その運動は非 回転性であると仮定する。流体の運動を記述する速度ポ テンシャルは次式のように表される4)。

$$
\Phi_{T}(t)=U \phi_{s}+\Phi(t)
$$




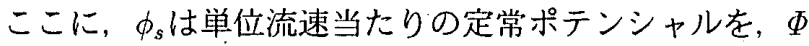
は非定常ポテンシャルを示す。 $\phi_{s}$ はさらに一様流れ $x$ と 物体の存在による定常撹乱ポテンシャルあに分解される。

$$
\phi_{s}=x+\bar{\phi}
$$

流速Uは小さく，O(U $\left.U^{2}\right)$ の項は無視できるものと仮定 すると, 定常擋乱ポテンシャル $\bar{\phi}$ 境界值問題は次式の ように表される ${ }^{4)}$ 。

$\nabla^{2} \bar{\phi}=0$ 流体領域 $V$ 内で

$\frac{\partial \bar{\phi}}{\partial z}=0 \quad$ 自由表面 $z=0$ 上で

$\frac{\partial \bar{\phi}}{\partial z}=0 \quad$ 底面 $z=-h$ 上で

$\frac{\partial \bar{\phi}}{\partial n}=-n_{1} \quad$ 物体表面 $S$ 上で

$\bar{\phi} \rightarrow 0 \quad$ 無限遠方 $\sqrt{x^{2}+y^{2}} \rightarrow \infty$ で.

ここに， $\partial / \partial n$ は $S$ 上に立てた外向き（流体領域から見 て）法線ベクトル $\mathbf{n}$ の方向の微分を， $n_{1}$ は $\mathrm{n}$ の $x$ 方向 余弦を示す。

非定常ポテンシャルゆは時間 $t$ の関数であり, 次式の ように記述される。

$$
\Phi(t)=\operatorname{Re}\left[\phi e^{-i \omega t}\right]
$$

複素ポテンシャル $\phi$ は入射波ポテンシャル $\phi_{I}$, 散乱波ポ

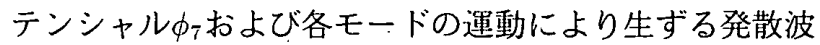
ポテンシャル $\phi_{j}(j=1, \ldots, 6)$ の和として次のように表 現される。

$$
\phi=\phi_{I}+\phi_{7}-i \omega \sum_{j=1}^{6} \xi_{j} \phi_{j}=\Phi_{7}-i \omega \sum_{j=1}^{6} \xi_{j} \Phi_{j}
$$

ここに

$$
\Phi_{j}=\left\{\begin{array}{l}
\phi_{j}, \quad j=1, \ldots, 6 \\
\phi_{I}+\phi_{\bar{\tau}}, \quad j=7
\end{array}\right.
$$

入射波ポテンシャルは既知であり, 次式によって与え られる。

$$
\phi_{1}=-\frac{i g \zeta_{0}}{\omega_{0}} \frac{\cosh k(z+h)}{\cosh k h} \mathrm{e}^{i k(x \cos \beta+y \sin \beta)}
$$

散乱波ポテンシャルおよび発散波ポテンシャルは次の 境界值問題の解として得られる ${ }^{4)}$ 。

$$
\begin{aligned}
& \nabla^{2} \Phi_{j}=0 \quad V \text { 内で } \\
& \frac{\partial \Phi_{j}}{\partial z}-\nu \Phi_{j}-2 i \tau \nabla \phi_{s} \cdot \nabla \Phi_{j} \\
& +i \tau \Phi_{j} \frac{\partial^{2} \phi_{s}}{\partial z^{2}}=O\left(\tau^{2}\right) \quad z=0 \text { で.... } \\
& \frac{\partial \Phi_{j}}{\partial z}=0 \quad z=-h \text { で }
\end{aligned}
$$

$$
\frac{\partial \Phi_{j}}{\partial n}=\left\{\begin{array}{l}
n_{j}+\frac{i \tau}{\nu} m_{j}, \quad j=1, \ldots, 6 \\
0, \quad j=7
\end{array} \quad\right. \text { S上で }
$$

$$
\begin{array}{r}
\sqrt{r}\left\{\frac{\partial \phi_{j}}{\partial r}-i\left[k+2 \tau \gamma_{0}(\cos \beta-\cos \theta) .\right.\right. \\
\left.\left.\quad+O\left(\tau^{2}\right)\right] \phi_{j}\right\} \rightarrow 0 \quad r \rightarrow \infty \text { で. }
\end{array}
$$

ここに,

$$
\begin{aligned}
& \nu=\frac{\omega^{2}}{g}, \quad \tau=\frac{\omega U}{g} \ldots \ldots \ldots \ldots \ldots . \\
& \left(n_{1}, n_{2}, n_{3}\right)=\mathbf{n} \ldots \ldots \ldots \ldots \ldots \\
& \left(n_{4}, n_{5}, n_{6}\right)=\mathbf{x} \times \mathbf{n} \ldots \ldots \ldots \ldots \ldots \\
& \left(m_{1}, m_{2}, m_{3}\right)=-(\mathbf{n} \cdot \nabla) \nabla \phi_{s} \ldots \ldots \ldots \\
& \left(m_{4}, m_{5}, m_{6}\right)=-(\mathbf{n} \cdot \nabla)\left(\mathbf{x} \times \nabla \phi_{s}\right) . \\
& \gamma_{0}=\frac{k^{2}}{\left(k^{2}-\nu_{0}^{2}\right) h+\nu_{0}} \ldots \ldots \ldots \\
& r=\sqrt{x^{2}+y^{2}}, \quad \theta=\tan ^{-1} \frac{y}{x} \ldots \ldots .
\end{aligned}
$$

$\mathrm{x}$ はS上の 1 点の浮体重心に対する相対位置べクトルを 示す。

\section{3. 積分方程式}

\section{1 定常問題}

定常擋乱ポテンシャル內の境界值問題 (6) は, グリー ンの公式を利用することによって, 次の積分方程式の解 に帰着される。

$$
\begin{aligned}
\left(\begin{array}{c}
4 \pi \\
\alpha
\end{array}\right) & \bar{\phi}(P)+\iint_{S} \bar{\phi}(Q) \frac{\partial \bar{G}(P, Q)}{\partial n} d S \\
& =\iint_{S} \vec{G}(P, Q) n_{1}(Q) d S \quad\left(\begin{array}{l}
P \in V \\
P \in S
\end{array}\right) \ldots
\end{aligned}
$$

ここに, $P(x, y, z)$ は参照点を, $Q(\xi, \eta, \zeta)$ は積分点を, $\bar{G}(P, Q)$ は自由表面上で剛壁条件 $\partial \overline{\bar{G}} / \partial \zeta=0$ を満たす グリーン関数を， $\alpha$ は点 $P$ において流体領域 $V$ のなす立 体内角を示す。

\section{2 . 非定常問題}

非定常ポテンシャル $\phi_{j}(j=1, \ldots, 7)$ を流速に比例す

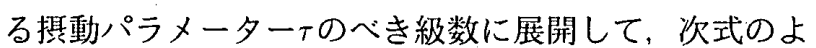
うに表示する。

$$
\phi_{j}=\phi_{j 0}+\tau \phi_{j 1}+O\left(\tau^{2}\right)
$$

ここに，(17) の第1 項は流れがない場合の波ポテンシャ ルを，第 2 項は流れの影響項を示す。

$\phi_{j}$ の境界值問題 (11) は, グリーンの公式と (17) を適 用することによって, 次の 2 つ積分方程式の解に㷌着 される10)。 


$$
\begin{aligned}
& \left(\begin{array}{c}
4 \pi \\
\alpha
\end{array}\right) \phi_{j 0}(P)+\iint_{S} \phi_{j 0}(Q) \frac{\partial G(P, Q)}{\partial n} d S \\
& =\left\{\begin{array}{r}
\iint_{S} G(P, Q) n_{j}(Q) d S, \quad j=1, \ldots, 6 \\
-\iint_{S} G(P, Q) \frac{\partial \phi_{I}(Q)}{\partial n} d S, \quad j=7 \\
\left(\begin{array}{l}
P \in V \\
P \in S
\end{array}\right) \ldots .
\end{array}\right.
\end{aligned}
$$

$$
\begin{aligned}
& \left(\begin{array}{c}
4 \pi \\
\alpha
\end{array}\right) \phi_{j 1}(P)+\iint_{S} \phi_{j 1}(Q) \frac{\partial G(P, Q)}{\partial n} d S \\
& =\iint_{S_{F}} G(P, Q) f(Q) d S \\
& +2 i \gamma_{0} \iint_{S_{\infty}} G(P, Q) \phi_{j 0}(Q)(\cos \beta-\cos \psi) d S \\
& \quad+\left\{\begin{array}{l}
\frac{i}{\nu_{0}} \iint_{S} G(P, Q) m_{j}(Q) d S, \quad j=1, \ldots, 6 \\
0, \quad j=7
\end{array}\right.
\end{aligned}
$$

$$
\left(\begin{array}{l}
P \in V \\
P \in S
\end{array}\right) \cdots
$$

ここに, $G(P, Q)$ は流れが不在の場合のグリーン関数を, $S_{F}$ は仮想遠方円筒境界面 $S_{\infty}$ によって囲まれた自由表面 の部分を示し，

$$
\begin{aligned}
& f(Q)=2 k \cos \beta \Phi_{j 0}(Q)+2 i \nabla \phi_{s}(Q) \cdot \nabla \Phi_{j 0}(Q) \\
& -i \Phi_{j 0}(Q) \frac{\partial^{2} \phi_{s}(Q)}{\partial \zeta^{2}} \\
& \Phi_{j 0}=\left\{\begin{array}{l}
\phi_{j 0}, \quad j=1, \ldots, 6 \\
\phi_{I}+\phi_{70}, \quad j=7
\end{array}\right. \\
& \rho=\sqrt{\xi^{2}+\eta^{2}}, \quad \psi=\tan ^{-1} \frac{\eta}{\xi}
\end{aligned}
$$

である。(5)，(10)，(21) を考慮すれば，fは一様流れ による項と定常擋乱ポテンシャルによる項とに分解され て, 次式のように表される。

$$
f(Q)=f_{U}(Q)+f_{S}(Q)
$$

ここに,

$$
\begin{aligned}
& f_{U}(Q)=2 k \cos \beta \phi_{j 0}(Q)+2 i \frac{\partial \phi_{j 0}(Q)}{\partial \xi} \ldots \ldots(2 \\
& f_{S}(Q)=2 i \nabla \bar{\phi}(Q) \cdot \nabla \Phi_{j 0}(Q)-i \Phi_{j 0}(Q) \frac{\partial^{2} \bar{\phi}(Q)}{\partial \zeta^{2}}
\end{aligned}
$$

\section{1 次非定常ポテンシャルの解}

積分方程式 (16), (18) を解いて, 定常擋乱ポテンシャ

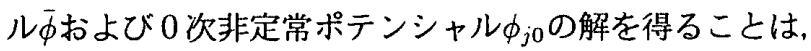
既存の回折プログラムを用いれば容易である。ここでは， 積分方程式 (19) を解いて 1 次非定常ポテンシャル $\phi_{j 1}$ の 解を得る方法について議論する。皘分方程式 (19) が (18)
之異なるところは，右辺の物体表面積分，自由表面積分 および遠方境界積分であるから，これらの積分が評価で きれば，既存の回折プログラムを用いて $\phi_{j 1}$ の解を得る ことができる。

\section{1 物体表面皘分の評価}

物体表面積分に含まれる $m_{j}$ 項は定常ポテンシャル $\phi_{s}$ の 2 階微分を含んでいるから，これらを数値的に精度良 く評価することは一般に困難である。この困難を避ける

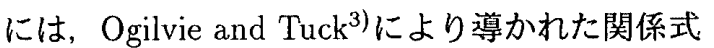

$$
\iint_{S} G m_{j} d S=-\iint_{S} \nabla G \cdot \nabla \phi_{s} n_{j} d S
$$

を用いると良い。 $(25)$ に含まれる $\phi_{s}$ の微分はすへて 1 階微分であるから，これらを数値微分により評価するの に特に困難はない。

\section{2 自由表面積分扰よび遠方境界積分の評価}

自由表面 $S_{F}$ 上の積分を評価するには， $S_{F}$ を仮想円形 境界 $C_{b}$ によって内部領域 $S_{F_{\text {in }}}$ と外部無限領域 $S_{F_{\text {out }}}$ に分 割すると都合が良い(Fig. 1) 。このとき，積分方程式 (19) は次式のように書きかえられる。

$$
\begin{aligned}
& \left(\begin{array}{c}
4 \pi \\
\alpha
\end{array}\right) \phi_{j 1}(P)+\iint_{S} \phi_{j 1}(Q) \frac{\partial G(P, Q)}{\partial n} d S \\
& \quad=F_{I}(P)+F_{U}(P)+F_{S}(P) \\
& \quad+\left\{\begin{array}{lr}
-\frac{i}{\nu_{0}} \iint_{S} \nabla G(P, Q) \cdot \nabla \phi_{s}(Q) n_{j}(Q) d S, \\
0, \quad j=7
\end{array}\right.
\end{aligned}
$$$$
\left(\begin{array}{l}
P \in V \\
P \in S
\end{array}\right)
$$

ここに,

$$
\begin{aligned}
F_{I}(P)= & \iint_{S_{\text {Fin }}} G(P, Q) f(Q) d S \ldots \ldots \ldots \ldots \\
F_{U}(P)= & \iint_{S_{\text {F }_{\text {out }}}} G(P, Q) f_{U}(Q) d S \\
& +2 i \gamma_{0} \iint_{S_{\infty}} G(P, Q) \phi_{j 0}(Q)(\cos \beta \\
& -\cos \psi) d S \ldots \ldots \ldots \ldots \ldots \ldots \ldots \\
F_{\mathcal{S}}(Q)= & \iint_{S_{\text {Fout }}} G(P, Q) f_{S}(Q) d S \ldots \ldots \ldots
\end{aligned}
$$

$S_{F_{\text {in }}}$ 上の積分 $F_{I}$ は数値積分により評価できる。ただし，

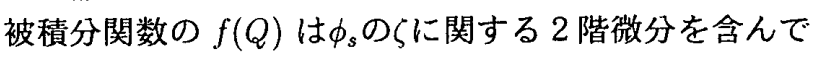
いるから，これを数值的に精度良く評価することは一般 に困難である。この困難を避けるには，2 次元グリーン の定理から導かれる次の関係式を用いると良い。$$
\iint_{S_{\text {Fin }}} G \Phi_{j 0} \frac{\partial^{2} \phi_{s}}{\partial \zeta^{2}} d S
$$

この式が使えるのは物体表面 $S$ が滑らかで，かつ自由表面と直 交する場合に限られる。

きこのような分割は，喫水線の半径が浮体の最大半径に一致する 場合には不要である。この場合には， $C_{b}$ を喫水線に一致させ， $S_{F}$ の全領域を $S_{F_{\text {out }}}$ として取り扱えば良い。
} 


$$
\begin{gathered}
=\iint_{S_{F i n}}\left(G \nabla \Phi_{j 0}+\Phi_{j 0} \nabla G\right) \cdot \nabla \phi_{s} d S \\
-\int_{C_{W}+C_{b}} \frac{\partial \dot{\phi}_{s}}{\partial n} \dot{d} C \ldots \ldots \ldots \ldots \ldots
\end{gathered}
$$

(28) 亡喫水線 $C_{W}$ 上での境界条件 $\partial \phi_{s} / \partial n=0$ を用いれ ば，FIは次のようにポテンシャルの 1 階微分のみを含む 形に書きかえられる。

$$
\begin{aligned}
F_{I}(P)= & \iint_{S_{F i n}}\left[2 k \cos \beta \Phi_{j 0}+i\left(G \nabla \Phi_{j 0}\right.\right. \\
& \left.\left.-\Phi_{j 0} \nabla G\right) \cdot \nabla \phi_{s}\right] d S+i \int_{C_{b}} \frac{\partial \phi_{s}}{\partial \rho} d C
\end{aligned}
$$

$S_{F_{\text {out }}}$ 上の積分 $F_{U}$ および $F_{S}$ は，ポテンシャルの遠方表 示を利用することによって，以下のように半解析的に評 価できる。

物体から十分離れた点では，０次非定常ポテンシャル $\phi_{j 0}$ は次式のように挙動する。

$$
\begin{aligned}
\phi_{j 0}= & \sum_{n=-\infty}^{\infty}\left[\left(\begin{array}{l}
A_{0, n} \\
B_{0, n}
\end{array}\right) H_{n}^{(1)}(k r) \frac{\cosh k(z+h)}{\cosh k h}\right. \\
& \left.+\sum_{m=1}^{\infty}\left(\begin{array}{l}
A_{m, n} \\
B_{m, n}
\end{array}\right) K_{n}\left(k_{m} r\right) \frac{\cos k_{m}(z+h)}{\cos k_{m} h}\right] \\
& \cdot\left(\begin{array}{c}
\cos \\
\sin
\end{array}\right) n \theta \ldots \ldots \ldots \ldots \ldots \ldots \ldots \ldots \ldots \ldots
\end{aligned}
$$

ここに,

$$
\begin{aligned}
& A_{0, n}=(-1)^{n} A_{0,-n}, \quad B_{0, n}=-(-1)^{n} B_{0,-n} \\
& A_{m, n}=A_{-m, n}, \quad B_{m, n}=-B_{m,-n} \quad(m \geq 1)
\end{aligned}
$$

で, $H_{n}^{(1)}$ は第 1 種ハンケル関数を, $K_{n}$ は第 2 種変形ベッ セル関数を示し， $k_{m}$ は次の固有方程式の正実根である。

$$
k_{m} \tan k_{m} h+\nu_{0}=0 \text {. }
$$

係数 $A_{m, n} ， B_{m, n}(m \geq 0)$ は，積分方程式 (18) を解いて 物体表面上のポテンシャル $\phi_{j 0}$ が得られれば決定できる 10)。

定常擋乱ポテンシャル 式のように表される。

$$
\begin{aligned}
\bar{\phi}= & {\left[\frac{\bar{A}_{0}}{r}+\sum_{m=1}^{\infty} \bar{A}_{m} K_{1}\left(\frac{m \pi r}{h}\right) \frac{\cos \frac{m \pi}{h}(z+h)}{\cos m \pi}\right] } \\
& \cdot \cos \theta \ldots \ldots \ldots \ldots \ldots \ldots \ldots \ldots \ldots \ldots \ldots \ldots \ldots \ldots \ldots
\end{aligned}
$$

係数 $\bar{A}_{m} \cdot(m \geq 0)$ は，積分方程式 (16) を解いて物体表面 上のポテンシャル市が得られれば決定できる。

ここでの目的のためには，グリーン関数 $G(P, Q)$ を次 のようにフーリエ級数に展開して表すと都合が良い。

$$
\mathrm{G}(P, Q)=\sum_{n=-\infty}^{\infty} g^{n}(r, z ; \rho ; \zeta) \cos n(\theta-\psi) \ldots
$$

$g^{n}$ は John ${ }^{13)}$ による $G$ の表示式をフーリエ展開して, 次 式のように表される14)。

$$
\begin{aligned}
& g^{n}(r, z ; \rho, \zeta)=2 \pi i \gamma_{0}\left(\begin{array}{l}
H_{n}^{(1)}(k r) J_{n}(k \rho) \\
J_{n}(k r) H_{n}^{(1)}(k \rho)
\end{array}\right) \\
& \cdot \frac{\cosh k(z+h) \cosh k(\zeta+h)}{\cosh ^{2} k h} \\
& +4 \sum_{m=1}^{\infty} \gamma_{m}\left(\begin{array}{l}
K_{n}\left(k_{m} r\right) I_{n}\left(k_{m} \rho\right) \\
I_{n}\left(k_{m} r\right) K_{n}\left(k_{m} \rho\right)
\end{array}\right) \\
& \quad \frac{\cos k_{m}(z+h) \cos k_{m}(\zeta+h)}{\cos ^{2} k_{m} h}\left(\begin{array}{l}
r>\rho \\
r<\rho
\end{array}\right)
\end{aligned}
$$

ここに,

$$
\gamma_{m}=\frac{k_{m}^{2}}{\left(k_{m}^{2}+\nu_{0}^{2}\right) h-\nu_{0}} .
$$

で， $J_{n}$ は第 1 種ベッセル関数を， $I_{n}$ は第 1 種変形ベッセ ル関数を示す。

(30)を(24a) に代入し, ベッセル関数の漸化式 ${ }^{15)}$ を用 いれば，fUは次式のように表される。

$$
\begin{aligned}
f_{U}= & \sum_{n=-\infty}^{\infty}\left[\left(\begin{array}{c}
C_{0, n} \\
D_{0, n}
\end{array}\right) H_{n}^{(1)}(k r)\right. \\
& \left.+\sum_{m=1}^{\infty}\left(\begin{array}{l}
C_{m, n} \\
D_{m, n}
\end{array}\right) K_{n}\left(k_{m} r\right)\right]\left(\begin{array}{c}
\cos \\
\sin
\end{array}\right) n \theta \ldots \ldots
\end{aligned}
$$

$こ こ に$

$$
\begin{aligned}
&\left(\begin{array}{c}
C_{0, n} \\
D_{0, n}
\end{array}\right)= 2 k \cos \beta\left(\begin{array}{l}
A_{0, n} \\
B_{0, n}
\end{array}\right)+i k\left(\begin{array}{l}
A_{0, n+1}-A_{0, n-1} \\
B_{0, n+1}-B_{0, n-1}
\end{array}\right) \\
& \ldots \ldots \ldots \ldots \ldots \ldots \ldots \ldots(37 \mathrm{a} \\
&\left(\begin{array}{c}
C_{m, n} \\
D_{m, n}
\end{array}\right)= 2 k \cos \beta\left(\begin{array}{c}
A_{m, n} \\
B_{m, n}
\end{array}\right) \\
&-i k_{m}\left(\begin{array}{c}
A_{m, n+1}+A_{m, n-1} \\
B_{m, n+1}+B_{m, n-1}
\end{array}\right) \ldots \ldots \ldots(37 \mathrm{~b})
\end{aligned}
$$

(30)，(33)，(34)，(36) を(27b) に代入し，付録に示 す積分公式 $(\mathrm{A} 1)-(\mathrm{A} 4)$ と $r \rightarrow \infty$ におけるハンケル関数 の漸近展開表示 ${ }^{15)}$ を用いれば， $S_{\infty}$ 上の積分は消去され て， $F_{U}$ は結局次式のように表される。

$$
\begin{aligned}
F_{U}(P) & =2 \pi \sum_{n=-\infty}^{\infty}\left[2 \pi i \gamma_{0}\left(\begin{array}{c}
\mathcal{I}_{0, n} \\
\mathcal{J}_{0, n}
\end{array}\right) J_{n}(k r)\right. \\
& \cdot \frac{\cosh k(z+h)}{\cosh k h}+4 \sum_{m=1}^{\infty} \gamma_{m}\left(\begin{array}{c}
\mathcal{I}_{m, n} \\
\mathcal{J}_{m, n}
\end{array}\right) I_{n}\left(k_{m} r\right) \\
& \left.\frac{\cos k_{m}(z+h)}{\cos k_{m} h}\right]\left(\begin{array}{c}
\cos \\
\sin
\end{array}\right) n \theta \ldots \ldots \ldots . . .38
\end{aligned}
$$

ここに，

$$
\begin{aligned}
\left(\begin{array}{c}
\mathcal{I}_{0, n} \\
\mathcal{J}_{0, n}
\end{array}\right) & =-\left(\begin{array}{c}
C_{0, n} \\
D_{0, n}
\end{array}\right) \frac{b^{2}}{2}\left[H_{n}^{(1)^{\prime}}(k b)^{2}+\left(1-\frac{n^{2}}{k^{2} b^{2}}\right)\right. \\
& \left.\cdot H_{n}^{(1)}(k b)^{2}\right]+\sum_{l=1}^{\infty}\left(\begin{array}{c}
C_{l, n} \\
D_{l, n}
\end{array}\right) \frac{b}{k^{2}+k_{l}^{2}} \\
& \cdot\left[k H_{n}^{(1)^{\prime}}(k b) K_{n}\left(k_{l} b\right)-k_{l} H_{n}^{(1)}(k b) K_{n}^{\prime}\left(k_{l} b\right)\right]
\end{aligned}
$$




$$
\begin{aligned}
\left(\begin{array}{c}
\mathcal{I}_{m, n} \\
\mathcal{J}_{m, n}
\end{array}\right) & =\left(\begin{array}{l}
C_{0, n} \\
D_{0, n}
\end{array}\right) \frac{b}{k^{2}+k_{m}^{2}}\left[k H_{n}^{(1)^{\prime}}(k b) K_{n}\left(k_{m} b\right)\right. \\
& \left.-k_{m} H_{n}^{(1)}(k b) K_{n}^{\prime}\left(k_{m} b\right)\right]+\left(\begin{array}{l}
C_{m, n} \\
D_{m, n}
\end{array}\right) \frac{b^{2}}{2} \\
& \cdot\left[K_{n}^{\prime}\left(k_{m} b\right)^{2}-\left(1+\frac{n^{2}}{k_{m}^{2} b^{2}}\right) K_{n}\left(k_{m} b\right)^{2}\right] \\
& +\sum_{\substack{l=1 \\
l \neq m}}^{\infty}\left(\begin{array}{c}
C_{l, n} \\
D_{l, n}
\end{array}\right) \frac{b}{k_{m}^{2}-k_{l}^{2}}\left[k_{l} K_{n}^{\prime}\left(k_{l} b\right) K_{n}\left(k_{m} b\right)\right. \\
& \left.-k_{m} K_{n}\left(k_{l} b\right) K_{n}^{\prime}\left(k_{m} b\right)\right] \ldots \ldots \ldots \ldots \ldots
\end{aligned}
$$

$b$ は仮想境界円 $C_{b}$ の半径を示す。

同様に, (10), (30), (32)を(24b)に代入し, ベッセル 関数の漸化式を用いれば， $f_{S}$ は次式のように表される。

$$
f_{S}=\sum_{n=-\infty}^{\infty}\left[f_{H}^{n}(r)+f_{K}^{n}(r)\right]\left(\begin{array}{c}
\cos \\
\sin
\end{array}\right) n \theta
$$

ここに,

$$
\begin{aligned}
& f_{H}^{n}(r)=\frac{i \bar{A}_{0} k}{r^{2}}\left[\left(\begin{array}{c}
A_{I, n+1} \\
B_{I, n+1}
\end{array}\right) J_{n+2}(k r)\right. \\
& -\left(\begin{array}{c}
A_{I, n-1} \\
B_{I, n-1}
\end{array}\right) J_{n-2}(k r)+\left(\begin{array}{c}
A_{0, n+1} \\
B_{0, n+1}
\end{array}\right) H_{n+2}^{(1)}(k r) \\
& \left.-\left(\begin{array}{c}
A_{0, n-1} \\
B_{0, n-1}
\end{array}\right) H_{n-2}^{(1)}(k r)\right] \\
& f_{K}^{n}(r)=\sum_{m=1}^{\infty}\left\{\frac { i \overline { A } _ { 0 } k _ { m } } { r ^ { 2 } } \left[\left(\begin{array}{c}
A_{m, n+1} \\
B_{m, n+1}
\end{array}\right) K_{n+2}\left(k_{m} r\right)\right.\right. \\
& \left.+\left(\begin{array}{c}
A_{m, n-1} \\
B_{m, n-1}
\end{array}\right) K_{n-2}\left(k_{m} r\right)\right]+i \bar{A}_{m}\left[\frac{m \pi}{h}\right. \\
& \cdot K_{1}^{\prime}\left(\frac{m \pi r}{h}\right) \frac{\partial}{\partial r}\left(\tilde{\Phi}_{j}^{n+1}(r)+\tilde{\Phi}_{j}^{n-1}(r)\right) \\
& +\left(\frac{m^{2} \pi^{2}}{2 h^{2}}+\frac{n+1}{r^{2}}\right) K_{1}\left(\frac{m \pi r}{h}\right) \tilde{\Phi}_{j}^{n+1}(r) \\
& \left.\left.+\left(\frac{m^{2} \pi^{2}}{2 h^{2}}-\frac{n-1}{r^{2}}\right) K_{1}\left(\frac{m \pi r}{h}\right) \tilde{\Phi}_{j}^{n-1}(r)\right]\right\} \\
& \left(\begin{array}{l}
A_{I, n} \\
B_{I, n}
\end{array}\right)=\left\{\begin{array}{l}
0, \quad j=1, \ldots, 6 \\
-\frac{i g \zeta_{0}}{\omega_{0}} i^{n}\left(\begin{array}{l}
\cos \\
\sin
\end{array}\right) n \beta, \quad j=7
\end{array}\right. \\
& \tilde{\Phi}_{j}^{n}(r)=\left(\begin{array}{c}
A_{I, n} \\
B_{I, n}
\end{array}\right) J_{n}(k r)+\left(\begin{array}{c}
A_{0, n} \\
B_{0, n}
\end{array}\right) H_{n}^{(1)}(k r) \\
& +\sum_{l=1}^{\infty}\left(\begin{array}{c}
A_{l, n} \\
B_{l, n}
\end{array}\right) K_{n}\left(k_{l} r\right)
\end{aligned}
$$

(33)，(34)，(40)を(27c) に代入し， $\psi$ に関する積分を 実行すれば， $F_{S}$ は次の形に表される。

$$
\begin{aligned}
F_{S}(P) & =2 \pi \sum_{n=-\infty}^{\infty}\left[2 \pi i \gamma_{0}\left(\begin{array}{l}
\mathcal{K}_{0, n} \\
\mathcal{L}_{0, n}
\end{array}\right) J_{n}(k r)\right. \\
& \cdot \frac{\cosh k(z+h)}{\cosh k h}+4 \sum_{m=1}^{\infty} \gamma_{m}\left(\begin{array}{l}
\mathcal{K}_{m, n} \\
\mathcal{L}_{m, n}
\end{array}\right) I_{n}\left(k_{m} r\right)
\end{aligned}
$$

$$
\left.\frac{\cos k_{m}(z+h)}{\cos k_{m} h}\right]\left(\begin{array}{c}
\cos \\
\sin
\end{array}\right) n \theta
$$

ここに,

$$
\begin{aligned}
& \left(\begin{array}{l}
\mathcal{K}_{0, n} \\
\mathcal{L}_{0, n}
\end{array}\right)=\int_{b}^{\infty}\left[f_{H}^{n}(\rho)+f_{K}^{n}(\rho)\right] H_{n}^{(1)}(k \rho) \rho d \rho . . \\
& \left(\begin{array}{l}
\mathcal{K}_{m, n} \\
\mathcal{L}_{m, n}
\end{array}\right)=\int_{b}^{\infty}\left[f_{H}^{n}(\rho)+f_{K}^{n}(\rho)\right] K_{n}\left(k_{m} \rho\right) \rho d \rho .(
\end{aligned}
$$

さらに，付録に示す積分公式 (A5), (A6) を用いれば, (45a) は次式のように書きかえられる。

$$
\begin{array}{r}
\left(\begin{array}{c}
\mathcal{K}_{0, n} \\
\mathcal{L}_{0, n}
\end{array}\right)=\frac{i \bar{A}_{0} k}{2}\left\{( \begin{array} { c } 
{ A _ { 0 , n + 1 } } \\
{ B _ { 0 , n + 1 } }
\end{array} ) \left[H_{n}^{(1)}(k b) H_{n+2}^{(1)}(k b)\right.\right. \\
\left.-H_{n+1}^{(1)}(k b)^{2}\right]-\left(\begin{array}{c}
A_{0, n-1} \\
B_{0, n-1}
\end{array}\right)\left[H_{n}^{(1)}(k b) H_{n-2}^{(1)}(k b)\right. \\
\left.-H_{n-1}^{(1)}(k b)^{2}\right]+\left(\begin{array}{c}
A_{I, n+1} \\
B_{I, n+1}
\end{array}\right)\left[H_{n}^{(1)}(k b) J_{n+2}(k b)\right. \\
\left.-H_{n+1}^{(1)}(k b) J_{n+1}(k b)\right]-\left(\begin{array}{c}
A_{I, n-1} \\
B_{I, n-1}
\end{array}\right) \\
\left.\cdot\left[H_{n}^{(1)}(k b) J_{n-2}(k b)-H_{n-1}^{(1)}(k b) J_{n-1}(k b)\right]\right\} \\
+\int_{b}^{\infty} f_{K}^{n}(\rho) H_{n}^{(1)}(k \rho) \rho d \rho \ldots \ldots \ldots \ldots . . . . . .(46)
\end{array}
$$

(45b) および (46) に含まれる積分の被積分関数は $\rho$ の增 加とともに指数関数的に減少して行くので，これらの積 分を数値積分により評価するのに特に困難はない。

積分方程式 (26) を物体表面上で満足させて解けば， 1 次非定常ポテンシャルの解が得られる。この積分方程式 の核関数は流れが不在の場合のグリーン関数であるから, 既存の回折プログラムを应張することによって, 容易に その解を得ることができる。特に, 浮体形状が回転対称 性を有する場合には，ポテンシャルを円周方向にフーリ エ展開することによって，面積分方程式を一連の線積分 方程式に変換することができ, 元の積分方程式を直接解 く場合に比へて, 計算効辫が大幅に改善される ${ }^{10) 。 ~}$

速度ポテンシャルが得られれば, ベルヌーイの定理を 用いて流体圧が, さらに物体表面に働く流体圧を積分す ることによって, 付加質量・減衰係数, 1 次波強制力お よび定常波漂流力が算定できる ${ }^{10)}$ 。

\section{5. 回転形浮体への適用}

前節までの理論を応用して，任意の子午線形状を有す る回転形浮体に㗢く流体力およびその応答を予測する計 算機プログラムを作成した。積分方程式を離散化して解 くために, Fig. 2 に示すように, 物体表面の子午線を 3 節点 2 次アイソパラメトリック要素に分割し, 各要素内 のポテンシャル分布を 2 次曲線で近似しだ。仮想内形 境界内部の自由表面積分の評価には, 自由表面の子午線

†波の回折・発散問題における 2 次要秦の優位性については多く の文献、たとえば文献 16)〜18)に指摘されている。 


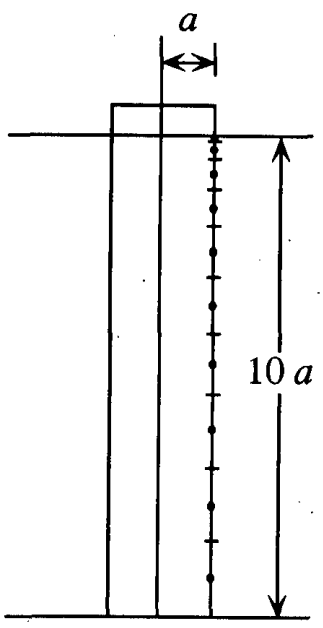

(a)

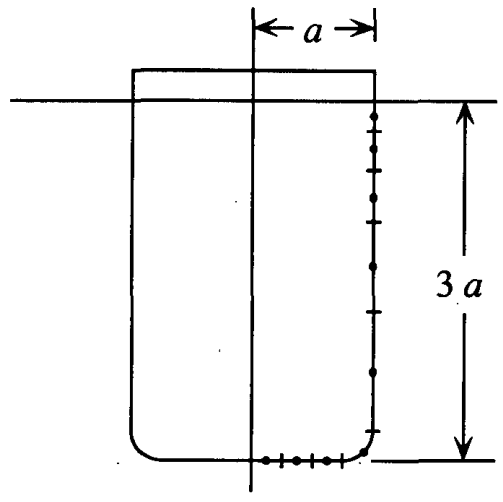

(b)

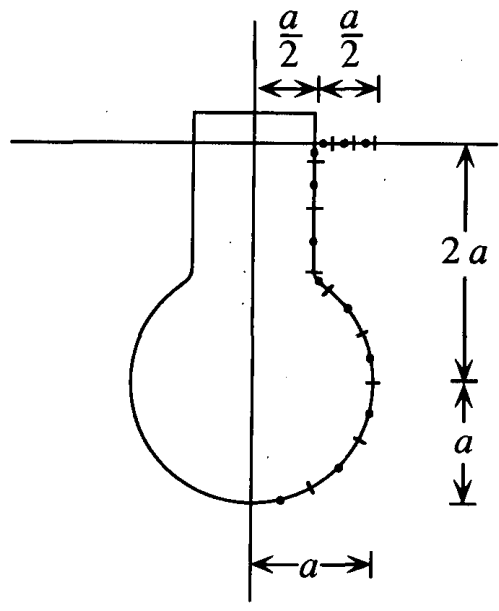

(c)

Fig. 2 Geometries and element idealisations for (a) uniform vertical cylinder, (b) truncated vertical cylinder, (c) floating dock of flask type.

を物体表面と同様の 2 次アイソパラメトリック要素に分 割し，各要素ごとにガウスの 4 点公式を適用した。ままた 外部無限領域の積分 (45b)，(46) の評価にはニュートン・ コーツ 9 点則を用い，相対誤差 $10^{-5}$ の精度で収束解が 得られるまで積分区間を逐次拡張する方法を採用した。 ポテンシャルのフーリエ級数展開の採用次数は $n=0$ か ら定常波漂流力の解が収束する $n=7$ までとした。また 固有関数展開項については上限を $m=30$ までとし，各 項ごとに収束判定を行い相対誤差が $10^{-5}$ 以下になった 時点で総和計算を終了させた。

\section{1 一様鉛直円柱}

最初に，本解析法の妥当性を検証するために，半径 $a$, 水樑 $h=10 a$ の一様鉛直円柱について, いくつかの予備 的な計算を行い, 解析解 ${ }^{9)}$ と比較した。積分方程式の離 散化に用いた要素分割をFig. 2(a)に示す。

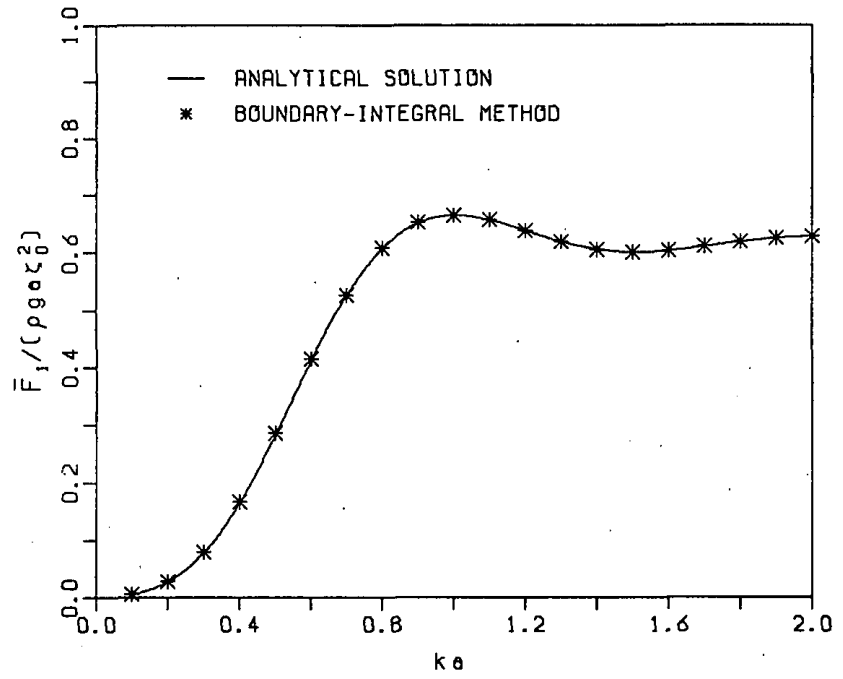

Fig. 3 Comparison between analytical and numerical results for mean drift force on uniform vertical cylinder (radius $=a$, water depth $=10 a$ ). $F n=0$.
Fig. 3 およびFig. 4 はそれぞれ定常波漂流力および波 漂流減衰係数の数值解之解析解の比較を示す。図中, 絴 軸の $\rho$ は流体密度を表す。なお，数值解における波漂流 減衰係数は $U=0$ の近傍における定常波漂流力の $U$ に 関する微係数を数值微分によって計算した結果である。 理論解亡数値解は非常に良く一致しており, 本解析法の 妥当性が確認できる。

\section{2 円筒形浮体}

次に，任意回転形浮体への適用例として，半径 $a ，$ 契 水深 $3 a$, 水深 $h=10 a$ の円筒形浮体が規則波とその 伝播方向に平行な流れを受ける場合 $(\beta=0)$ について 計算を行った。積分方程式の離散化に用いた要素分割を Fig. 2(b) に示す。なお，隅角部の丸みは物体表面の不連 続性による処理の煩雑さを避けるために人為的に付加し たものである。

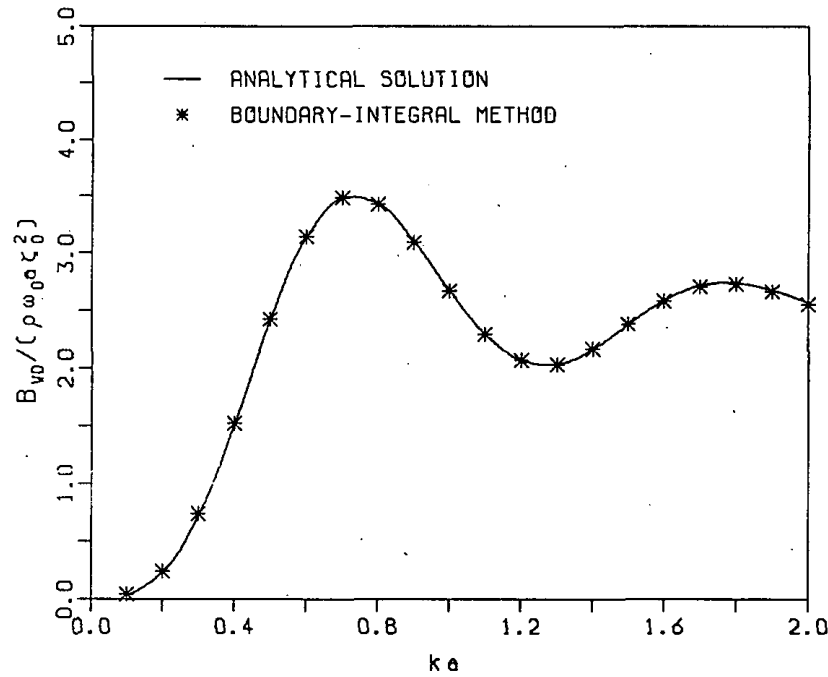

Fig. 4 Comparison between analytical and numerical results for wave drift damping coefficient for uniform vertical cylinder (radius $=a$, water $\operatorname{depth}=10 a) . \beta=0$. 


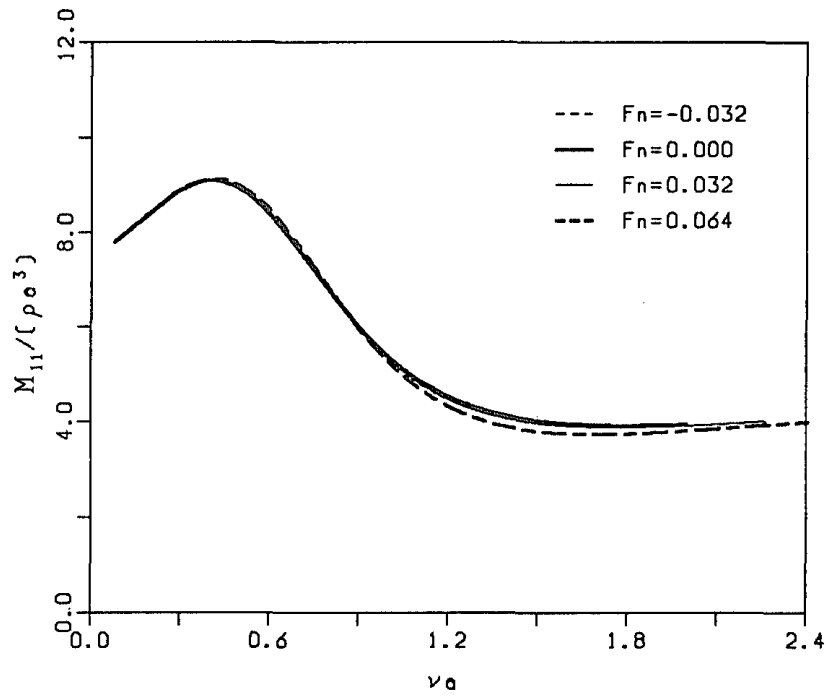

Fig. 5 .Added mass coefficient in surge for truncated vertical cylinder (radius $=a$, draught $=3 a$, water $\operatorname{depth}=10 a)$

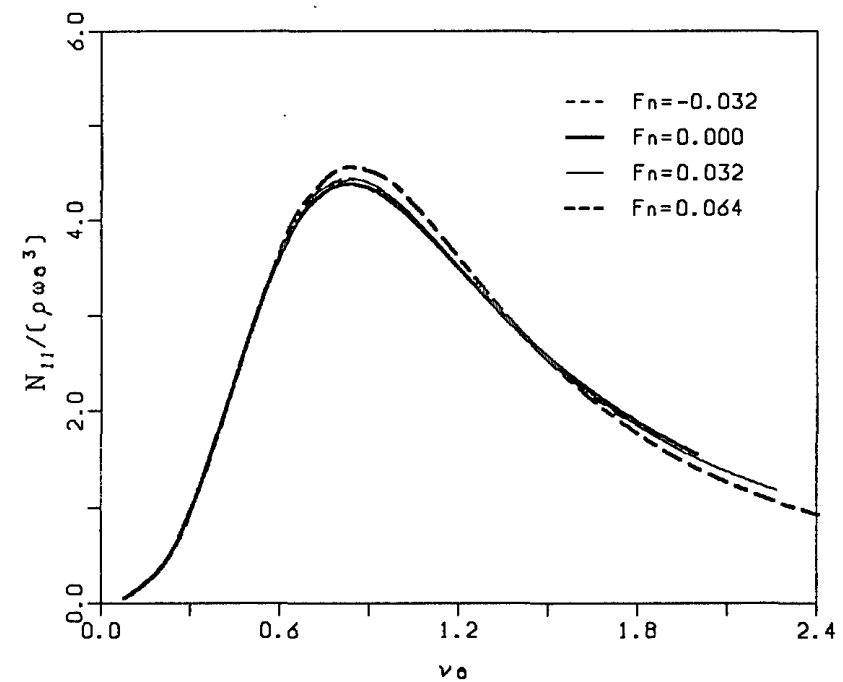

Fig. 6 Added damping coefficient in surge for truncated vertical cylinder (radius $=a$, draught $=3 a$, water depth=10a).

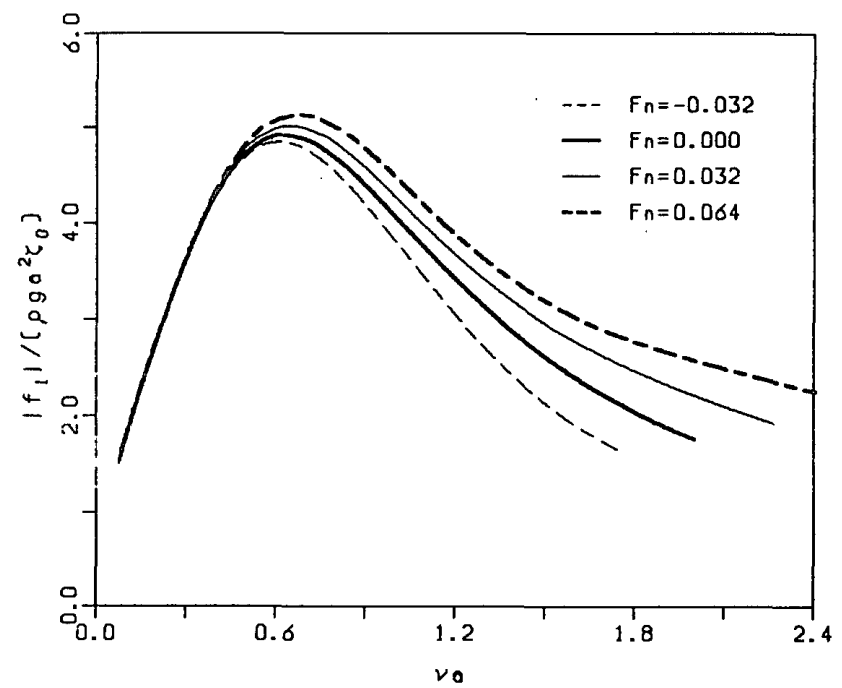

Fig. 7 Surge wave exciting force on truncated vertical cylinder (radius $=a$, draught $=3 a$, water depth $=10 a$ ).

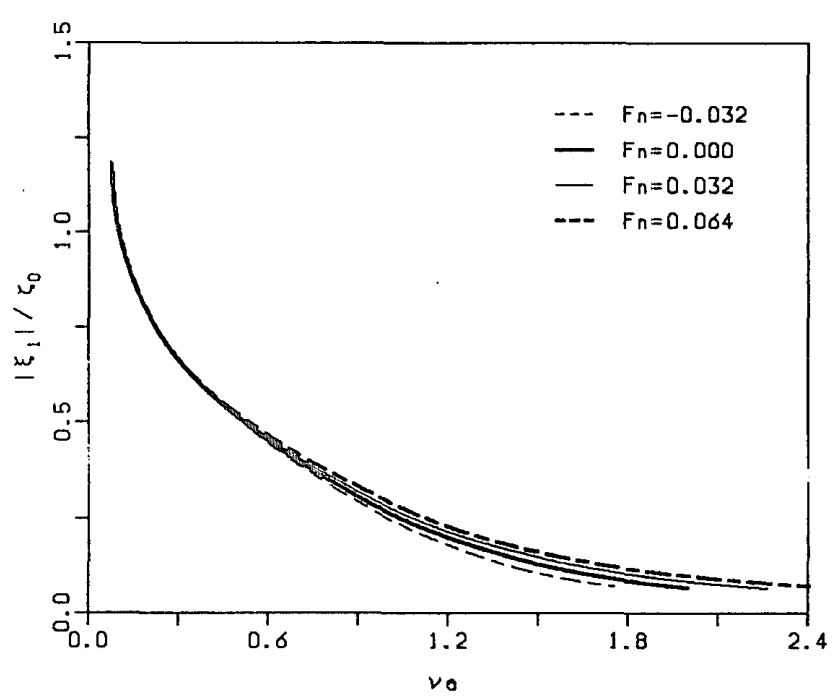

Fig. 8 Surge response of floating truncated vertical cylinder (radius $=a$, draught $=3 a$, water $\operatorname{depth}=10 a$ ). Heave and pitch motions are restraint.

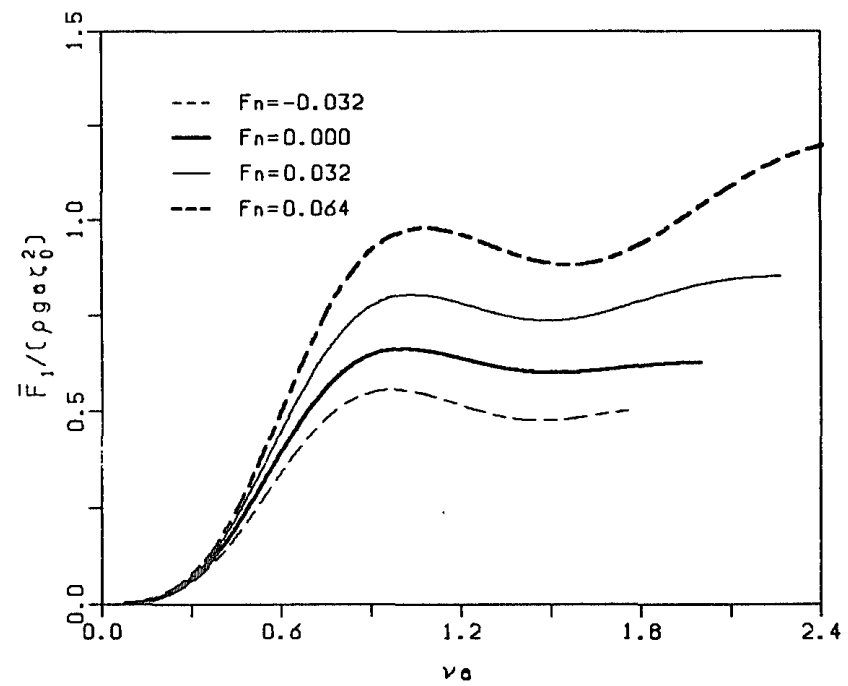

Fig. 9 Mean surge drift force on fixed truncated vertical cylinder (radius $=a$, draught $=3 a$, water $\operatorname{depth}=10 a$ ).

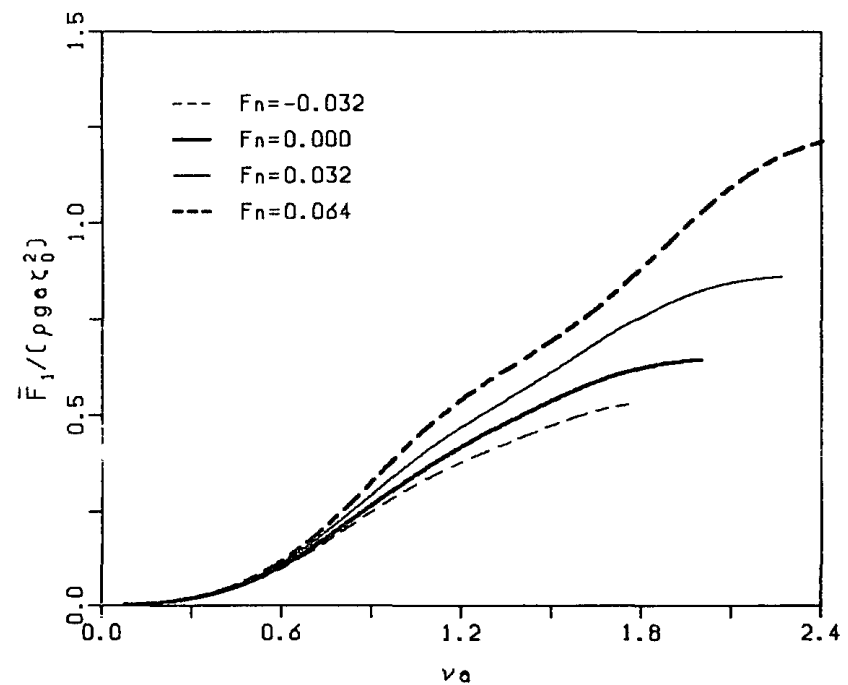

Fig. 10 Mean surge drift force on floating truncated vertical cylinder (radius $=a, \quad$ draught $=3 a$, water depth $=10 a$ ). Heave and pitch motions are restraint. 


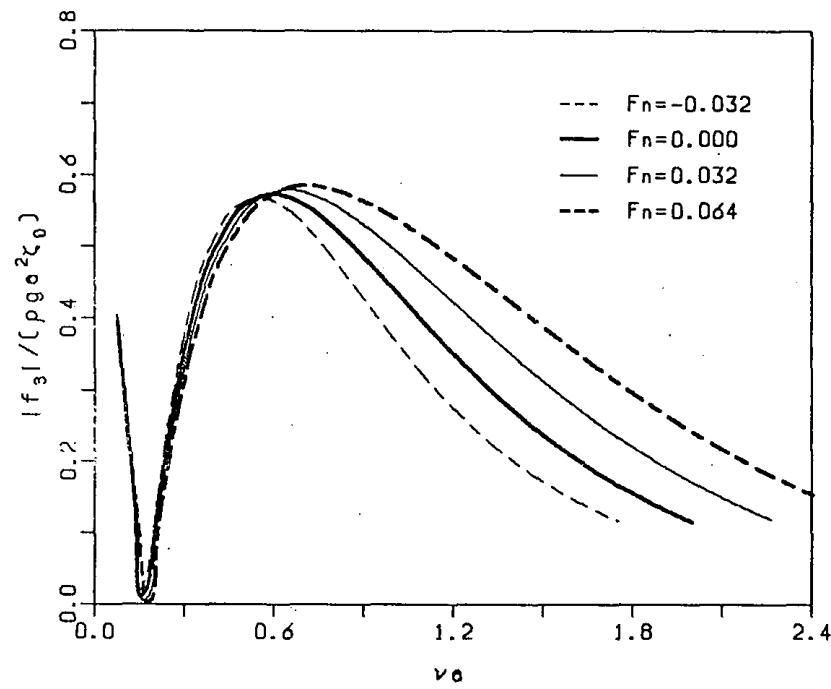

Fig. 11 Heave wave exciting force on floating dock of flask type (pontoon radius $=a$, column radius $=0.5 a$, draught $=3 a$, water depth $=10 a$ ).

計算結果を Figs. 5-10に揭げるす。図中の横軸は無次元 化出会い波数 $\nu a=\omega^{2} a / g$ を, また Fn はフルード数を表 し, $F n^{\prime}=U / \sqrt{2 g a}$ で定義される。たとえば, $a=12.5 \mathrm{~m}$ とすれば, $U=0.5 \mathrm{~ms}^{-1}$ のとき $F n=0.032$ の值を得る。

Fig. 5 およびFig. 6 はそれぞれサージ付加質量係数お よびサージ付加減衰係数の計算結果を示す。流れによっ て出会い周波数が変化する影響を除けば，付加質量・減衰 係数に及ぼす流れの影響は極めて小さいことがわかる。

Fig. 7 はサージ1 次波強制力の計算結果を示す。サー 济波強制力は，波と流れの方向が一致する，いわゆる向 かい波状態 $(F n>0)$ では, 流れのない場合に比へて増 加し，波之流秃の方向が逆転する，いわゆる追い波状態 $(F n<0)$ では減少する。この傾向は出会い周波数が高 くなるほど顕著になる。

Fig. 8 はサージ運動応答の計算結果を示す。ただし， 浮体のヒーブ運動およびピッチ運動は拘束され，サージ 運動のみが許容されていると仮定している。1 次波強制 力の結果に対応して, 高周波数域ではサージ応答が流れ によって僅かであるが影響を受けているのが観察できる。

Fig. 9 およびFig. 10 はそれぞれ浮体運動を拘束した 場合およびサージ運動が許容された場合のサージ定常波 漂流力の計算結果を示す。向かい波状態 $(F n>0)$ では, 定常波漂流力は流れの存在によって增加し，追い波状態 $(F n<0)$ では減少する傾向を呈する。Figs. 7，8 と比 較して, 定常波漂流力の方が 1 次波強制力や運動応答よ りも流れの存在によってより顕著な影響を受けることが 理解される。

\section{3 フラスコ形浮体}

より複雑な形状に対する本手法の有効性を示す例とし

\footnotetext{
†より詳細な結果は文献 19)に掲载されている。
}

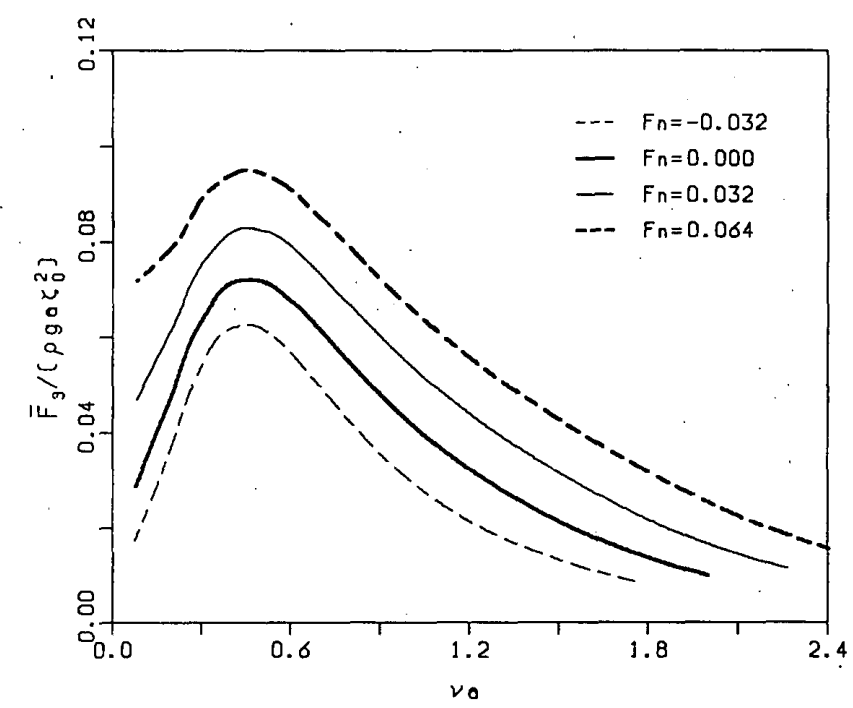

Fig. 12 Mean heave drift force on floating dock of flask type (pontoon radius $=a$, column radius $=0.5 a$, draught $=3 a$, water depth $=10 a$ ). Heave and pitch motions are restraint.

て，Fig. 2(c) に示すような形状のフラスコ形浮体が規 則波とその伝播方向に平行な流れを受ける場合について 計算を行った。浮体はヒーブ運動扰よびピッチ運動が拘 束され，サージ運動のみが許容されていると仮定した。 積分方程式の離散化および自由表面積分の評価に用いた 要素分割を Fig. 2(c)に示す。ただし，仮想円形境界の 半径は $b=a(a$ : ポンツーン部の半径) に設定されてい る。ヒーブ 1 次波強制力およびヒ一ブ定常波漂流力の計 算結果を Fig. 11 および Fig. 12 に掲げる。流れの存在 によって波強制力や波漂流力が著しい影響を受けている のが観察できる。

\section{6. 結語}

一様な流れ之規則波の複合作用を受ける回転形浮体に 働く流体力およびその運動応答を，ポテンシャル流れと 低流速の仮定に基づき予測する新しい数值解析手法を提 案し, いくつかの典型的な浮体に適用して, 流体力や浮 体の応答に及ぼす流れの影響について考察した。

本研究の結果得られた知見は以下のように要約される。

1）波と流れの共存場では，波による流体力および浮 体の応答は流れの存在によって著しい影響を受ける。

2) 付加質量係数および付加減衰係数は, 流れによっ て出会い周波数が変化する影響を除けば，流れの存在に よってほとんど影響を受けない。

3) サージ 1 次波強制力やサージ定常波漂流力は, 向 かい波状態では流れのない場合よりも增加し，追い波状 態では減少する。この傾向は出会い周波数が高くなるほ ど顕著になる。

4）1次波強制力や運動応答よりも定常波漂流力の方 が流れの存在によってより大きな影響を受ける。 
本稿で提案した境界積分方程式による解法は，流れが 不在の場合のグリーン関数を用いるので，一様流れ場の グリーン関数に基づく既往の解法に比べて，グリーン関 数の計算に要する労力が少なくてすみ, 既存の回折プロ グラムを拡張するだけで容易に流れの影響を考慮するこ とができる。本解析法を 3 次元任意形状浮体にも適用で きるよう拡張することは容易であり，この拡張について は稿を改めて報告する予定である。

\section{参考文献}

1) Wichers, J.E.W., and van Sluijs, M.F.: The Influence of Waves on the Low-Frequency Hydrodynamic Coefficients of Moored Vessels, Proc. Offsh. Tech. Conf., Houston, OTC 3625, pp. 2313-2324, 1979.

2) Wichers, J.E.W., and Huijsmans, R.H.M.: On the Low Frequency Hydrodynamic Damping Forces Acting on Offshore Moored Vessels, Proc. Offsh. Tech. Conf., Houston, OTC 4831, pp 315-321, 1984.

3) Ogilvie, T.F., and Tuck, E.O.: A Rational Strip Theory for Ship Motions: Part 1, Dept. Nav. Arch. Mar. Eng. Rept., No. 013, Univ. of Michigan, 1969.

4) Newman, J.N.: The Theory of Ship Motions, Advance in Applied Mechanics, Vol. 18, pp. 221-283, 1978.

5) たとえば, Chang, M.S.: Computation of ThreeDimensional Ship Motions with Forward Speed, Proc. 2nd Int. Conf. on Numer. Ship Hydrodyn., Berkeley, pp. $124-135,1977$.

6) Wehausen, J.V., and Laitone, E.V.: Surface Wave, Handbuch der Physik, Vol. 9, pp. 446-778, 1960.

7) Zhao, R., Faltinsen, O.M., Krokstad, J.R., and Aanesland, V.: Wave-Current Interaction Effects on LargeVolume Structures, Proc. 5th Int. Conf. on Behav. Offsh. Struct., Trondheim, 1988.

8) Huijsmans, R.H.M., and Hermans, A.J.: A Fast Algorithm for Computation of 3-D Ship Motions at Moderate Forward Speed, Proc. 4th Int. Conf. on Numer. Ship Hydrodyn., Washington D.C., 1985.

9）松井徹哉, 李 相曄, 佐野公俊：波之流れの共存場に 置かれた鉛直円柱に加わる流体力，日本造船学会論文 集、第 170 号, pp. 277-287, 1991.

10）松井徹哉，李 相瞱：波と流れの複合作用を受ける半 球形浮体に働く流体力およびその応答，日本建築学会 構造系論文報告集，第 443 号，pp. 277-287, 1993.

11) Nossen, J., Grue, J., and Palm, E.: Wave Forces on Three-Dimensional Floating Bodies with Small Forward Speed, J. Fluid Mech., Vol. 227, pp. 135-160, 1991.

12) Grue, J., and Biberg, D.: Wave Forces on Marine Structures with Small Speed in Water of Restricted Depth, Appl. Ocean Res., Vol. 15, pp. 121-135, 1993.
13) John, F.: On the Motion of Floating Bodies II, Comm. Pure Appl. Math., Vol. 3, pp. 45-101, 1950.

14) Fenton, J.D.: Wave Forces on Vertical Bodies of Revolution, J. Fluid Mech., Vol. 85, Part 2, pp. 241-255, 1978.

15) Abramowitz, M., and Stegun, I.A.: Handbook of Mathematical Functions, 9th ed., Dover, New York, 1972.

16）松井徹哉，加藤賢治：ハイブリッド型積分方程式法に よる浮体の定常動摇問題の数値解析, 日本建築学会構 造系論文報告集, 第 393 号, pp. 165-176, 1988.

17) Liu, Y.H., Kim, C.H., and Lu, X.S.: Comparison of Higher-Order Boundary Element and Constant Panel Method for Hydrodynamic Loadings, Int. J. Offshore and Polar Eng., Vol. 1, No. 1, pp. 8-17, 1991.

18) Matsui, T., and Kato, K.: The Analysis of WaveInduced Dynamics of Ocean Platforms by Hybrid Integral-Equation Method, Int. J. Offshore and Polar Eng., Vol. 1, No. 2, pp. 146-153, 1991.

19）李 相曄：海洋構造物の挙動に及ぼす波一流扎相互干涉 効果に関する解析的研究, 名古屋大学博士学位請求論 文, 1993.

付録. 䅣分公式

(39) および (46) を導くに際して利用した積分公式を以下 に揭げておく

$$
\begin{aligned}
& \int H_{n}^{(1)}(k \rho)^{2} \rho d \rho \\
& =\frac{\rho^{2}}{2}\left[H_{n}^{(1)^{\prime}}(k \rho)^{2}+\left(1-\frac{n^{2}}{k^{2} \rho^{2}}\right) H_{n}^{(1)}(k \rho)^{2}\right] \ldots \\
& \int H_{n}^{(1)}(k \rho) K_{n}\left(k_{m} \rho\right) \rho d \rho=\frac{\rho}{k^{2}+k_{m}^{2}} \\
& \cdot\left[k_{m} H_{n}^{(1)}(k \rho) K_{n}^{\prime}\left(k_{m} \rho\right)-k H_{n}^{(1)^{\prime}}(k \rho) K_{n}\left(k_{m} \rho\right)\right] \\
& \int K_{n}\left(k_{l} \rho\right)^{2} \rho d \rho \\
& =\frac{\rho^{2}}{2}\left[-K_{n}^{\prime}\left(k_{l} \rho\right)^{2}+\left(1+\frac{n^{2}}{k_{l}^{2} \rho^{2}}\right) K_{n}\left(k_{l} \rho\right)^{2}\right] . . \\
& \int K_{n}\left(k_{l} \rho\right) K_{n}\left(k_{m} \rho\right) \rho d \rho=\frac{\rho}{k_{m}^{2}-k_{l}^{2}} \\
& \cdot\left[k_{m} K_{n}\left(k_{l} \rho\right) K_{n}^{\prime}\left(k_{m} \rho\right)-k_{l} K_{n}^{\prime \prime}\left(k_{l} \rho\right) K_{n}\left(k_{m} \rho\right)\right] \\
& \int H_{n}^{(1)}(k \rho) H_{n \pm 2}^{(1)}(k \rho) \frac{d \rho}{\rho} \\
& =\frac{1}{2}\left[H_{n \pm 1}^{(1)}(k \rho)^{2}-H_{n}^{(1)}(k \rho) H_{n \pm 2}^{(1)}(k \rho)\right] . \\
& \int H_{n}^{(1)}(k \rho) \cdot J_{n \pm 2}(k \rho) \frac{d \rho}{\rho} \\
& =\frac{1}{2}\left[H_{n \pm 1}^{(1)}(k \rho) J_{n \pm 1}(k \rho)-H_{n}^{(1)}(k \rho) J_{n \pm 2}(k \rho)\right]
\end{aligned}
$$$$
(l \neq m) \ldots(\mathrm{A} 4)
$$

(1994 年 4 月 4 日原稿受理, 1994 年 10 月 14 日採用決定) 